\title{
Spatio-temporal variability in the GDH activity to ammonium excretion ratio in epipelagic marine zooplankton
}

\author{
I. Fernández-Urruzola* ${ }^{*}$ N. Osma, T.T. Packard, F. Maldonado, M. Gómez \\ Marine Ecophysiology Group (EOMAR), Universidad de Las Palmas de Gran Canaria, 35017, Spain.
}

\begin{abstract}
Glutamate dehydrogenase (GDH) activities have been widely used in oceanographic research as an index of in situ $\mathrm{NH}_{4}^{+}$excretion rates $\left(R_{\mathrm{NH}_{4}^{+}}\right)$in zooplankton. Here we study the variability in the relationship between the enzymatic rates and the actual rates measured in epipelagic marine zooplankton between several marine ecosystems. Although both measures were significantly correlated across zooplankton assemblages, the regression models yielded different $\mathrm{GDH} / R_{\mathrm{NH}_{4}^{+}}$ratios across ecosystems. Accordingly, the error of a general equation increased up to $\pm 42.5 \%$ when regressing all our data together. Aside from possible interspecific differences, some of the variability was explained by the unequal allometric relation that each rate maintained with protein. Scaling exponents were 1.38 for GDH activities and 0.87 for $R_{\mathrm{NH}_{4}^{+}}$, which would induce uncertainties in the $\mathrm{GDH} / R_{\mathrm{NH}_{4}^{+}}$ratios when organisms with different sizes were considered. Nevertheless, the main factor causing divergence between GDH activities and $R_{\mathrm{NH}_{4}^{+}}$was the potential prey availability. We compared the excretory metabolism of the zooplankton community at different productivity periods in waters off Gran Canaria, and observed an important decrease in the $R_{\mathrm{NH}_{4}^{+}}$during stratification. A similar decrease was found in the internal pool of glutamate, which may be critical in the regulation of in vivo rates. Strengthening our knowledge of the relationship between GDH activities and the $R_{\mathrm{NH}_{4}^{+}}$will lead to more meaningful predictions of phytoplankton regeneration and community nitrogen fluxes across large spatial scales.

Keywords: Zooplankton, Glutamate dehydrogenase (GDH), Ammonium excretion, Allometry, Intracellular glutamate
\end{abstract}

\section{Introduction}

Nitrogen is one of the most limiting nutrient elements controlling phytoplankton growth throughout the world's oceans. The dissolved inorganic nitrogen availability may come either from remineralization processes in the sunlit layer or from introduction of new nutrients via upwelling, dinitrogen fixation and terrestrial run-off. Among all the inorganic nitrogen species, the recycling of the reduced form of ammonium $\left(\mathrm{NH}_{4}^{+}\right)$satisfies a global mean of about

${ }^{*}$ Corresponding author. Tel.: +34 9284544 73; fax: +34 928452922

Email address: ifernandez@becarios.ulpgc.es (l. Fernández-Urruzola*) 
$80 \%$ of the primary production requirements (Harrison, 1992). It is therefore an outstanding source of nitrogen to be considered when assessing nutrient fluxes in any aquatic ecosystem.

The regeneration of $\mathrm{NH}_{4}^{+}$is mainly the result of both bacterial remineralization of dissolved organic matter and excretion processes in zooplankton (Bronk and Steinberg, 2008). Here we focus on this latter component of the nitrogen cycle. The importance of $\mathrm{NH}_{4}^{+}$excretion by zooplankton is closely related to the trophic character of the ecosystem and it is, in general terms, more important in oligotrophic than in eutrophic waters. Accordingly, mesozooplankton $\mathrm{NH}_{4}^{+}$excretion has been found to be responsible from about $90 \%$ of the primary production in oligotrophic gyres (Isla et al., 2004) to a low of $5 \%$ in upwelling environments (Bode et al., 2004; Fernández-Urruzola et al., 2014). However, the $\mathrm{NH}_{4}^{+}$excretion rates $\left(R_{\mathrm{NH}_{4}^{+}}\right)$are also affected by the temperature, taxa, body size and nutritional level (Steinberg and Saba, 2008), so their potential contribution to the marine biogeochemical cycles varies widely in both time and space, highlighting the need for monitoring the zooplankton physiology in order to understand this variability. Unfortunately, measuring $R_{\mathrm{NH}_{4}^{+}}$on live zooplankton is, not only burdened by unavoidable uncertainties, but so time consuming that rarely enough incubations can be made to obtain a high-resolution spatial coverage of $R_{\mathrm{NH}_{4}^{+}}$. This becomes even more complicated if different size fractions of zooplankton are to be studied. Aside from the effort investment, in vitro measurements of zooplankton metabolism are subjected to several sources of error. Factors such as crowding, stress caused during manipulation, and starvation in the ongoing experiments would promote a rapid fall in the $R_{\mathrm{NH}_{4}^{+}}$(Bidigare, 1983; Ikeda et al., 2000). Conversely, organisms injured either during collection or handling are prone to release more nutrients than do the healthy specimens (Ikeda et al., 1982). All these effects result in excretion rates that, to some extent, might be different from normal $R_{\mathrm{NH}_{4}^{+}}$in seawater.

As part of the biochemical machinery, enzymes catalyze the synthesis of many metabolic end-products and therefore, they have been extensively used in oceanography to infer rates of particular physiological processes such as, for example, respiration (Packard et al., 1971), nitrate uptake (Eppley, 1978) or $\mathrm{NH}_{4}^{+}$excretion (Bidigare and King, 1981). Enzymatic assays constitute a relatively straightforward way to study the plankton metabolism that circumvents all the methodological constraints associated with bottle incubations. Moreover, enzyme activities can be measured quickly, either on-board or at a later time, as long as the biological samples were properly stored. This confers on the enzymatic assays an advantage over the more direct incubation techniques. Prompted by these arguments, Bidigare and King (1981) introduced the analysis of the glutamate dehydrogenase (GDH) activity as a proxy for $R_{\mathrm{NH}_{4}^{+}}$in zooplankton. Since then, the GDH assay has been used to obtain a detailed $R_{\mathrm{NH}_{4}^{+}}$distribution, both depth resolved and across ocean regions, at sampling rates that otherwise would not have been attainable (e.g., Bidigare et al., 1982; King et al., 1987; Fernández-Urruzola et al., 2014). More recently, Fernández-Urruzola et al. (unpublished data) modeled downward nitrogen fluxes from GDH measurements through the water column in the northern Benguela. But enzymatic assays, such as the one for GDH, are not exempt from methodological biases. They are measurements that reflect the maximum rate at which the reaction may occur, not the actual one, so they have to be converted into in situ rates through an empirical factor. However, the relationship between enzymatic and in vivo rates is not universal, but may be affected by the ambiental conditions. In fact, Bamstedt (1980) demonstrated that enzymes respond to the environ- 
mental changes with a certain delay as compared to the physiological response. This was subsequently corroborated for different metabolic pathways when varying food availability in cultures of marine mysids (Herrera et al., 2011; Fernández-Urruzola et al., 2011).

During a year (2011), we conducted on-board incubations of mixed epipelagic zooplankton throughout different marine systems: North Atlantic, Benguela Upwelling and Indian Ocean. Here we present both the $R_{\mathrm{NH}_{4}^{+}}$and GDH activities measured at each province, and provide the most complete $\mathrm{GDH} / \mathrm{R}_{\mathrm{NH}}^{+}$data set published to date for marine zooplankton. We compare our ratios with those found in the literature either for natural mixed zooplankton or cultured organisms, and discuss the use of a generalized $\mathrm{GDH} / R_{\mathrm{NH}_{4}^{+}}$ratio for routinely assessing in vivo $R_{\mathrm{NH}_{4}^{+}}$from GDH measurements. Furthermore, oceanic mixing events may induce trophic shifts that would locally impact the relationship between GDH activity and $R_{\mathrm{NH}_{4}^{+}}$in the resident zooplankton community. For this reason, we chose a station off Gran Canaria $\left(28^{\circ} \mathrm{N}\right)$ to evaluate the magnitude of the seasonal changes in the biomass-specific rates from the same location in comparison to variability found between different oceanic systems. In this light, we measured the intracellular levels of the main substrate for the GDH reaction, i.e., glutamate, to explore the correlation between physiological rates and substrate concentration. If the latter controls the former, then both should follow the same trend in response to the environmental changes.

\section{Material and methods}

\subsection{Study regions}

The spatial variability of both $R_{\mathrm{NH}_{4}^{+}}$and GDH activities in zooplankton were analyzed from five cruises that were carried out during 2011. These cruises surveyed tropical and temperate waters of the Indian Ocean (IO), North Atlantic (NA), Canary islands (CI), and Benguela upwelling (BU) system (Fig. 1). The temporal variability in the zooplankton metabolism was also assessed by sampling the same station off Taliarte, Gran Canaria Island (2800’03” N, 15¹9’30” W) during the so-called "late winter bloom" (CI-LWB, characterized by the nutrient-enrichment of surface waters through mixing processes), and during the period of maximum stratification (CI-ST, with higher temperatures and a lower nutrient load in the sunlit layer that is expected to limit the phytoplankton growth). In all the cases we followed the same experimental procedure in order to minimize any bias associated with the methodology. Zooplankton were collected by vertical tows with a UNESCO WP-2 net $(60 \mathrm{~cm}$ diameter ring, fitted with either $100 \mu \mathrm{m}$ or $200 \mu \mathrm{m}$ mesh sizes depending on the cruise) from $200 \mathrm{~m}$ to the surface (i.e., the epipelagic zone). Additionally, a HansenEgg plankton net with a mouth opening of $20 \mathrm{~cm}$, and fitted with a $50 \mu \mathrm{m}$ mesh size, was used during the CI-LWB cruise to extend our study into the $50-100 \mu \mathrm{m}$ size fraction. The hauling speed was always about $0.2-0.3 \mathrm{~m} \mathrm{~s}^{-1}$, as recommended for physiological studies of live zooplankton (Sameoto et al., 2000). Once on deck, organisms were carefully fractionated into $50-100 \mu \mathrm{m}, 100-200 \mu \mathrm{m}, 200-500 \mu \mathrm{m}, 500-1000 \mu \mathrm{m}$ and > $1000 \mu \mathrm{m}$ size categories. This fractionation varied according to the mesh size of the sampling-net, and how much zooplankton were gathered in the net. Each size fraction was then transferred by siphoning into 2-L bottles filled with GF/F filtered seawater, 


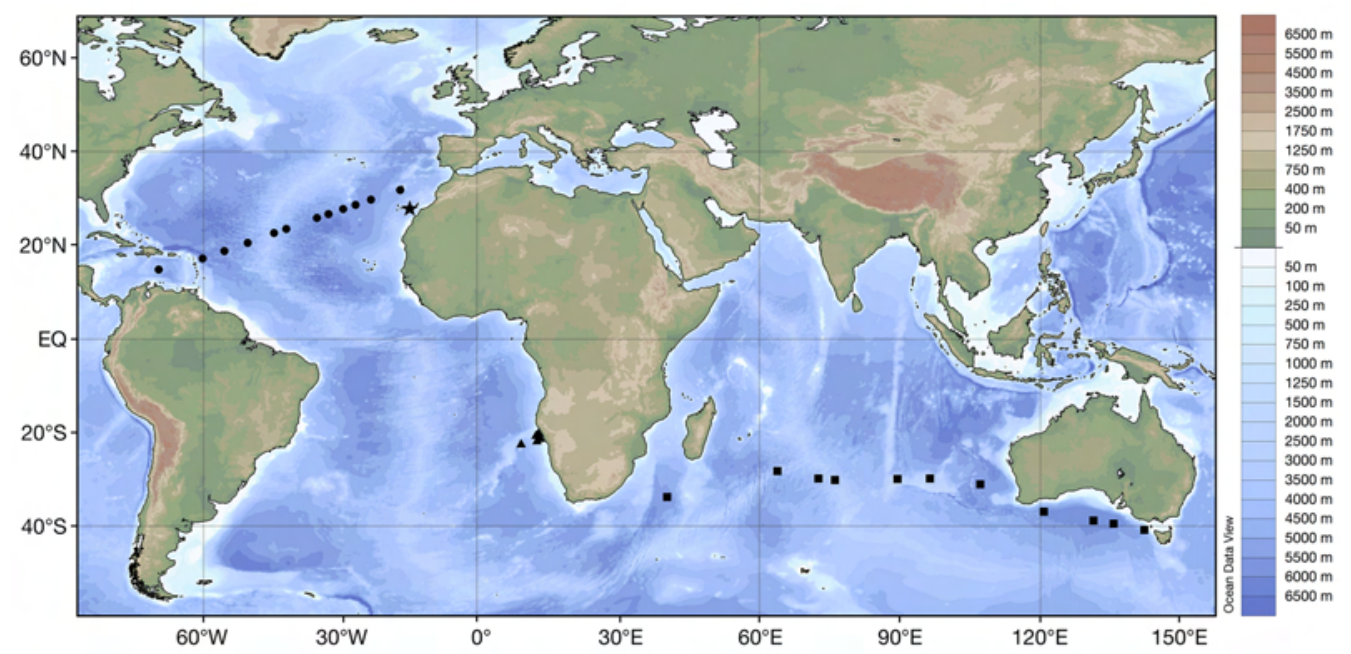

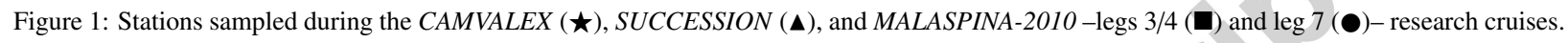
All samples were taken from Feb-2011 to Oct-2011. To compare seasonal differences in the zooplankton $\mathrm{NH}_{4}^{+}$excretory metabolism, the Camvalex cruise was conducted twice off Taliarte (Canary islands): during the so-called late winter bloom (Apr-2011), and during the period of maximum stratification (Oct-2011).

and maintained at in situ temperature. During the acclimation period, the bottles were gently aerated with an air pump, taking care not to damage the organisms with the bubbles. The zooplankton were thus acclimated for about an hour before being used in the $\mathrm{NH}_{4}^{+}$excretion experiments in order to reduce the stress incurred during the course of sampling.

\subsection{Chlorophyll-a determinations}

Chlorophyll-a (Chl-a) was measured for each oceanic system as an estimator of phytoplankton biomass. Seawater was filtered through GF/F and, in some cases, stored at $-20{ }^{\circ} \mathrm{C}$ for subsequent analyses. Pigments were extracted in acetone, and their concentration was determined according to two different methods depending on the cruise. The Chl-a samples from the NA and the IO were measured onboard using their fluorescence properties as described by Yentsch and Menzel (1963), while the Chl-a concentration in the CI-LWB, CI-ST and BU was spectrophotometrically analyzed in the land-based laboratory following the protocol of Parsons et al. (1984).

\subsection{Bottle incubations}

After acclimation, the most healthy and actively swimming zooplankters were washed in GF/F filtered seawater and siphoned into $60 \mathrm{~mL}$ gas-tight glass bottles. Each experimental batch included, at least, one control flask without organisms. We found little effect of container size on the oxygen consumption rates when varying the experimental bottles from $30 \mathrm{~mL}$ to $160 \mathrm{~mL}$ (Ikeda et al., 2000), so we chose a volume in the lower range in order to reduce the incubation time. Thus, we obtained a significant signal of $\mathrm{NH}_{4}^{+}$release in less than $1.5 \mathrm{~h}$. This achieved a 
compromise between those effects that density and starvation may induce on the physiological rates, and which are fairly constant over $1.5 \mathrm{~h}$ of incubation. Shortly before the incubation began, we took three replicates $(10 \mathrm{~mL}$ each one) of filtered seawater to determine the dissolved $\mathrm{NH}_{4}^{+}$concentrations $(\mu \mathrm{M})$ at the starting point. Then, we incubated the organisms at in situ temperature (after averaging the temperatures for the upper $200 \mathrm{~m}$ ) and in the dark for $1-1.5$ $\mathrm{h}$, depending on the density of the experimental population. Darkness was meant to prevent any autotrophic activity that could utilize the available dissolved $\mathrm{NH}_{4}^{+}$. Afterwards, $10 \mathrm{~mL}$ of seawater were siphoned off from each bottle for $\mathrm{NH}_{4}^{+}$determinations. Dissolved $\mathrm{NH}_{4}^{+}$was spectrofluorometrically measured according to the Holmes et al. (1999) method, except in the "SUCCESSION" cruise where it was determined through the phenol-hypochlorite method (Solorzano, 1969) due to the inability to measure fluorescence on board. We used a standard curve from 0.04 to $10.24 \mu \mathrm{M}$ to calibrate both the fluorescence and absorbance measurements. For the calculations of $\mathrm{NH}_{4}^{+}$excretion rates, we subtracted the $\mathrm{NH}_{4}^{+}$concentration quantified in the control flasks from those concentrations measured in the experimental flasks.

\subsection{Enzymatic measurements}

Once the seawater was sampled for $\mathrm{NH}_{4}^{+}$excretion analyses, the zooplankters were immediately frozen in liquid nitrogen $\left(-196{ }^{\circ} \mathrm{C}\right)$ and stored at $-80{ }^{\circ} \mathrm{C}$ until enzyme analyses in the land-based laboratory. Organisms were then thawed, and sonicated for $45 \mathrm{~s}$ in $0.1 \mathrm{M}$ Tris-buffer medium, made up to $\mathrm{pH} 8.6$ with acetic acid. The resulting homogenate was centrifuged for $8 \mathrm{~min}$ at $4000 \mathrm{rpm}$. The whole process prior to the enzymatic assay never exceeded $20 \mathrm{~min}$, with the samples being kept at $0{ }^{\circ} \mathrm{C}$ at all times. The supernatant was then assayed for glutamate dehydrogenase (GDH) activity following the method published in Bidigare and King (1981), slightly modified by applying the principles of fluorometry as explained in Fernández-Urruzola et al. (2011) to detect the NADH production rate in the reaction. To ensure that the maximum velocity $\left(V_{\max }\right)$ of the reaction was reached, i.e., the potential enzymatic rate, we saturated the enzyme with $50 \mathrm{mM}$ glutamate and $1.2 \mathrm{mM}$ nicotinamide adenine dinucleotide $\left(\mathrm{NAD}^{+}\right)$. Furthermore, $2 \mathrm{mM}$ adenosine-5' -diphosphate (ADP) was added to favor the glutamate deamination that could be inhibited to some degree by guanosine-5'-triphosphate (GTP) molecules present in the homogenate. In addition, for those samples collected off the Canary Islands, an aliquot of the supernatant fluid was simultaneously assayed for electron transport system (ETS) activity according to the Owens and King's (1975) protocol. This allowed us to evaluate seasonal changes in the $R_{\mathrm{O}_{2}} / R_{\mathrm{NH}_{4}^{+}}$ratios. The two enzyme reactions were kinetically measured for 4 min at the same temperature used in the incubation experiments, so no temperature correction (Arrhenius equation) was needed.

\subsection{Intracellular concentration of glutamate}

We further studied the intracellular levels of the main substrate of the reaction (glutamate) in order to relate any temporal variation in the $\mathrm{NH}_{4}^{+}$excretion rates at the $\mathrm{CI}$ station with biochemical adjustments of the GDH. Among other factors, the concentration of available glutamate will be critical to determine the rate at which the GDH can operate. Accordingly, we analyzed the intracellular concentration of free glutamate by applying the method of Beutler and 
Michal (1974), which uses diaphorase, tetrazolium salts and pure GDH from bovine liver (EC 1.4.1.3) to determine the glutamate concentration in the sample. This method overcomes the equilibrium of the GDH reaction by the continuous reoxidation of the NADH formed from the glutamate deamination (Eq. 1), through coupling with a second enzyme reaction catalyzed by diaphorase (Eq. 2):

$$
\text { Glutamate }+\mathrm{NAD}^{+}+\mathrm{H}_{2} \mathrm{O} \stackrel{\mathrm{GDH}}{\rightleftharpoons} \alpha-\text { Ketoglutarate }+\mathrm{NADH}+\mathrm{NH}_{4}^{+}
$$

$$
\mathrm{NADH}+\mathrm{INT}+\mathrm{H}^{+} \stackrel{\text { Diaphorase }}{\rightleftharpoons} \mathrm{NAD}^{+}+\text {Formazan }
$$

Since the reaction proceeds stoichiometrically, we derive the intracellular glutamate concentration from quantifying the total formazan production, whose extinction coefficient is measured at $492 \mathrm{~nm}$.

\subsection{Biomass determination}

Biomass was estimated as protein content using the Lowry method (Lowry et al., 1951) modified by Rutter (1967). Bovine serum albumine (BSA) was used as a standard.

\subsection{Statistics}

Statistical analyses were performed using SPSS for Macintosh (v 22, Inc., Chicago, USA). The normal distribution of data and the variance homogeneity were confirmed by the Shapiro-Wilk and the Levene's tests, respectively. An ANCOVA test was applied to check for significant differences between the $R_{\mathrm{NH}_{4}^{+}}$-protein and the GDH activitiesprotein slopes. Differences in the $R_{\mathrm{NH}_{4}^{+}}$and GDH activities between locations and size categories were determined by one-way ANOVA tests. When necessary, Box-Cox analyses were applied to find the best transformations of the protein-specific data in order to achieve normality and homoscedasticity. All the regression equations and confidence intervals (CIs) were calculated using Sigmaplot (v 12.5, Systat Software Inc., California, USA).

\section{Results}

\subsection{Characteristics of the study sites}

Sampling dates and oceanographic properties of the different provinces studied during 2011 are presented in Table 1, along with the number of experiments conducted in each region. Mean sea surface temperature (SST) ranged from a low of $14.6{ }^{\circ} \mathrm{C}$ in the BU to a high of $25.1{ }^{\circ} \mathrm{C}$ in the NA. The opposite trend was observed in the averaged chlorophyll-a values, with their maximum in the $\mathrm{BU}\left(3.18 \mathrm{mg} \mathrm{m}^{-3}\right)$ and the minimum in the NA $\left(0.08 \mathrm{mg} \mathrm{m}^{-3}\right)$. Both variables reflected the features typical of upwelling and oligotrophic environments, respectively. There were fewer, but still noticeable, seasonal differences in the hydrographical properties in the Canary Islands waters; during the late winter bloom period (CI-LWB) the waters were colder and had more phytoplankton biomass than during October (Table 1). 
Table 1: Cruise name and regions sampled during 2011 for $\mathrm{NH}_{4}^{+}$excretion and GDH analyses in zooplankton. SST and SSS stand for the sea surface temperature and salinity, respectively. The range min - max (mean) is given for each physical or biological variable. The last column (exp. number) indicates the number of incubations performed at each cruise.

\begin{tabular}{|c|c|c|c|c|c|c|}
\hline Cruise & Region & $\begin{array}{c}\text { Study season } \\
\text { (in 2011) }\end{array}$ & $\begin{array}{l}\text { SST } \\
\left({ }^{\circ} \mathrm{C}\right)\end{array}$ & $\begin{array}{c}\text { SSS } \\
\text { (PSU) }\end{array}$ & $\begin{array}{c}\text { Chl-a } \\
\left(\mathrm{mg} \mathrm{m}^{-3}\right)\end{array}$ & $\begin{array}{c}\text { Exp. } \\
\text { number }\end{array}$ \\
\hline \multirow[t]{2}{*}{ Malaspina 2010} & Indian Ocean & Feb. - Mar. & $16.5-25.9(21.5)$ & $34.8-36.0(35.5)$ & $0.04-0.52(0.18)$ & 23 \\
\hline & North Atlantic & Jun. - Jul. & $21.1-28.8(25.1)$ & $34.5-35.4(34.9)$ & $0.04-0.27(0.08)$ & 57 \\
\hline \multirow[t]{2}{*}{ Camvalex } & Canary Islands & Apr. & $18.2-20.8(19.3)$ & $36.6-38.8(36.7)$ & $0.33-0.36(0.34)$ & 83 \\
\hline & & Oct. & $20.6-23.3(22.1)$ & $36.8-36.9(36.9)$ & $0.22-0.26(0.24)$ & 52 \\
\hline Succession & Northern Benguela & Aug. - Sep. & $12.8-16.2(14.6)$ & $34.4-35.8(34.8)$ & $0.75-14.34(3.18)$ & 32 \\
\hline
\end{tabular}

\section{2. $\mathrm{NH}_{4}^{+}$excretory metabolism of zooplankton}

Fig. 2 shows the relationship between protein content in the sample and both $R_{\mathrm{NH}_{4}^{+}}$and GDH activities from the different marine systems surveyed, disregarding the potential effect of in situ temperature. Both variables were significantly correlated with the biomass $(p<0.0001)$, even though the variance in the GDH activities that was explained by the protein content ( $62 \%$ ) was twice that for $R_{\mathrm{NH}_{4}^{+}}(29 \%)$. On the other hand, the slopes of the regression analyses were significantly different from each other (ANCOVA test, $F_{1,243}=16.39, p<0.01$ ), which would cause variability in the $\mathrm{GDH} / R_{\mathrm{NH}_{4}^{+}}$ratio with biomass.

$R_{\mathrm{NH}_{4}^{+}}$and GDH activities were then standardized by protein for comparison between areas and size fractions (Fig. 3). It is noteworthy that no large zooplankton $(>1000 \mu \mathrm{m})$ were captured in the net during CI-LWB. This was not the case in BU, where only the zooplankton between $500-1000 \mu \mathrm{m}$ were considered due to methodological problems in the other size categories (since they were either contaminated with diatom chains in the case of the $100-500 \mu \mathrm{m}$ size fraction, or below the detection limit of the method in the case of the $>1000 \mu \mathrm{m}$ size fraction). Biomass specific- $R_{\mathrm{NH}_{4}^{+}}$ indicated some allometry as they were, in general, higher in the smaller size fraction (Table 2). Considering the study area, the most significant differences in $R_{\mathrm{NH}_{4}^{+}}$were found at CI-ST and BU, where the $\mathrm{NH}_{4}^{+}$release per unit of protein showed the lowest rates (Table 2). This variability was attributed mainly to the smaller size fractions, since the $R_{\mathrm{NH}_{4}^{+}}$ in the largest zooplankton $\left(>1000 \mu \mathrm{m}\right.$ ) was relatively invariant between the different regions (ANOVA test, $F_{2,28}=$ $1.55, p=0.231$ ). As expected for potential measurements, the protein specific-GDH activities were always higher than their correspondent $R_{\mathrm{NH}_{4}^{+}}$(Fig. 3b). GDH activities depicted, however, a different pattern than those observed for $R_{\mathrm{NH}_{4}^{+}}$. In fact, the differences with size fraction followed the opposite trend, with the GDH activities higher in the largest organisms (Table 2). The variability in the GDH between regions was not so marked although, paradoxically, CI-LWB presented the lowest GDH activities. Nevertheless, considering the zooplankton between $100-1000 \mu \mathrm{m}$, the GDH activities between CI-LWB and CI-ST were comparable (Student $t$-test, $p>0.05$ ).

The relationships between GDH activities and $R_{\mathrm{NH}_{4}^{+}}$at each location and size fraction, expressed as $\mu \mathrm{mol} \mathrm{NH}_{4}^{+}$ $\mathrm{mg}$ protein ${ }^{-1} \mathrm{~h}^{-1}$, are presented in Table 3 . Both variables were linearly related in all cases, so no transformations 

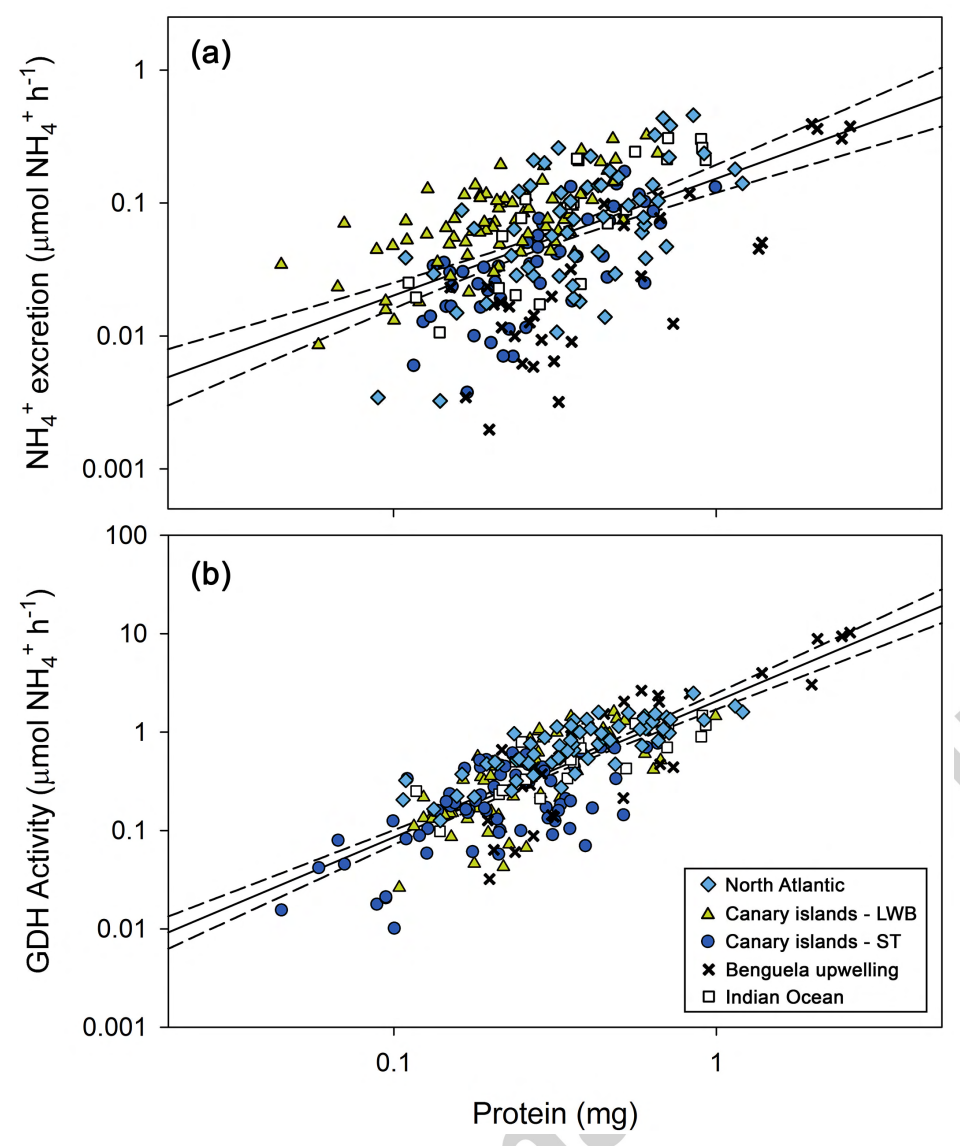

Figure 2: Log-scale scatterplot showing the relationship between protein content and $\mathrm{NH}_{4}^{+}$excretion rates (a), and between protein content and GDH activities (b). Each data point represents different size fractions of mixed zooplankton, incubated at in situ temperature (ranging from 12.8 to $28.8^{\circ}$ C). The least-square linear regressions were: $\log R_{\mathrm{NH}_{4}^{+}}=0.87 \log$ protein $-0.82\left(r^{2}=0.29, n=243, p<0.0001\right)$ for $\mathrm{NH}_{4}^{+}$excretion rates, and $\log G D H=1.38 \log$ protein $+0.31\left(r^{2}=0.62, n=247, p<0.0001\right)$ for GDH activities. Dashed lines stand for the $95 \% C I s$.

were applied to the data. Furthermore, each data set was normally distributed (Shapiro-Wilk test, $p>0.05$ ), and their variance was constant across observations (Levene's test, $p>0.05$ ). This allowed us to extract meaningful regression statistics and compare our slopes, which define the GDH to $R_{\mathrm{NH}_{4}^{+}}$ratio, with other published GDH/ $R_{\mathrm{NH}}{ }_{4}^{+}$means. These slopes were similar between the NA, IO and CI-LWB, ranging from 1.7 (NA) to 2.3 (IO) for the whole community. Furthermore, the ratio measured at the CI-LWB compared well with those reported in the literature for the same area and season (Fernández-Urruzola et al., 2011; Hernández-León and Torres, 1997). However, the GDH to $R_{\mathrm{NH}_{4}^{+}}$ relationship increased dramatically up to 6-fold during the stratification period, at the CI-ST $(=13.27, p<0.0001)$. Zooplankters from other ecosystems were characterized by a higher GDH/ $R_{\mathrm{NH}_{4}^{+}}$ratio, with a maximum of 43.8 in the marine mysid Praunus flexuosus (Bidigare and King, 1981). In general, the error of estimates (SEE) was lower in the monospecific experiments than in those samples of mixed zooplankton. Seeking a common relationship for all the study areas, we pooled all our experimental data in Fig. 4. In this case, both rates (in $\mu$ mol $\mathrm{NH}_{4}^{+} \mathrm{sample}^{-1}$ 
$\mathrm{h}^{-1}$ units) were logarithmically transformed to reduce heteroscedasticity of the residuals, and we found the following relationship:

$$
\begin{gathered}
\log G D H=0.64 \log R_{\mathrm{NH}_{4}^{+}}+0.36 \\
\left(r^{2}=0.37, n=235, p<0.0001, S E E= \pm 42.6 \%\right)
\end{gathered}
$$

The values from the five cruises were distributed uniformly along the regression line, but all together generated a higher dispersion as compared to the one observed for each individual cruise. Accordingly, the standard error of the estimate in Eq. 3 was twice the errors found when regressing each cruise separately. Still, the linear model for the whole data set was significant at $p<0.0001$. Considering a multivariate regression in the form of

$$
\begin{gathered}
\log G D H=-2.25+0.72 \log R_{\mathrm{NH}_{4}^{+}}+0.12 T+0.42 C h l-a \\
\left(r^{2}=0.59, n=235, p<0.0001, S E E= \pm 34.5 \%\right)
\end{gathered}
$$
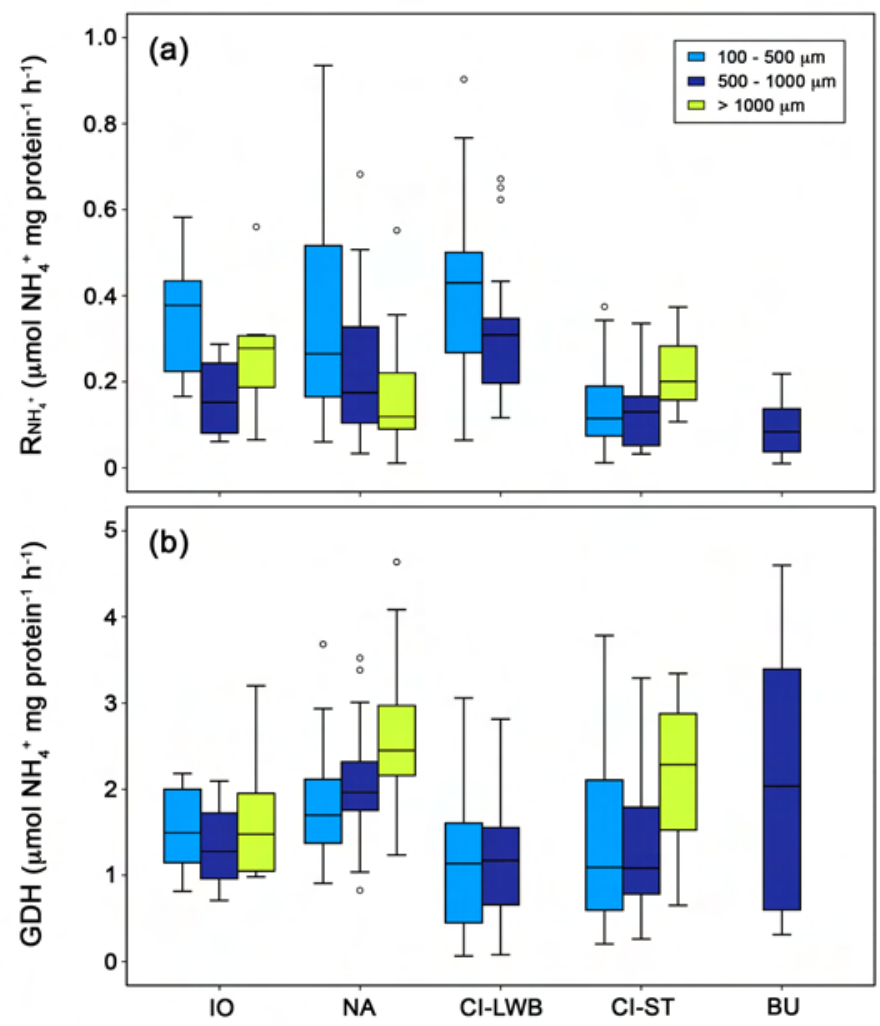

Figure 3: Boxplot showing the biomass-specific $\mathrm{NH}_{4}^{+}$excretion rates (a), and the biomass-specific GDH activities (b) in three size categories of zooplankton throughout different marine ecosystems. The lower and upper boundaries of the boxes represent the first and third quartiles of the data distribution, respectively, with the middle line indicating the median. Error bars indicate the $95 \% \mathrm{CIs}$. 
Table 2: One-way ANOVA results for $R_{\mathrm{NH}_{4}^{+}}$and GDH activities (both in $\mu$ mol $\mathrm{NH}_{4}^{+}$protein ${ }^{-1} \mathrm{~h}^{-1}$ ). The factors, location and size, were applied separately, since not all the size categories were available in all five locations. Box-Cox analysis was applied wherever variable transformation was necessary to validate ANOVA. Accordingly, the square root was found to be the best transformation of the data.

\begin{tabular}{|c|c|c|c|c|c|}
\hline$R_{N H_{4}^{+}}$ & $d f$ & $M S$ & $F$ & $p$-value & Pairwise comparison (Tukey's test) \\
\hline Location & 4 & 0.50 & 27.06 & * & CI-LWB $>\left[\mathrm{IO}^{* * *}, \mathrm{NA}^{* *},(\mathrm{CI}-\mathrm{ST}, \mathrm{BU})^{*}\right]$ \\
\hline Residual & 219 & 0.02 & & & {$[\mathrm{IO}, \mathrm{NA}]>\left[\mathrm{CI}-\mathrm{ST}^{* * *}, \mathrm{BU}^{*}\right]$} \\
\hline Size & 2 & 0.32 & 13.00 & $* *$ & $100 \mu \mathrm{m}>\left[1000 \mu \mathrm{m}^{* * *}, 500 \mu \mathrm{m}^{*}\right]$ \\
\hline Residual & 221 & 0.02 & & & \\
\hline \multicolumn{6}{|l|}{$G D H$} \\
\hline Location & 4 & 5.60 & 7.77 & $*$ & $\mathrm{NA}>\left[\mathrm{CI}-\mathrm{LWB}^{*}, \mathrm{CI}^{-\mathrm{ST}^{* *}}\right]$ \\
\hline Residual & 216 & 0.72 & & & $\mathrm{BU}>\mathrm{CI}-\mathrm{LWB}^{* * * *}$ \\
\hline Size & 2 & 5.61 & 7.33 & $*$ & $1000 \mu \mathrm{m}>\left[500 \mu \mathrm{m}^{* * * *}, 100 \mu\right.$ \\
\hline Residual & 218 & 0.77 & & & \\
\hline
\end{tabular}

${ }^{*}$ Significant at a level $p<0.001,{ }^{* *} p<0.01$, and ${ }^{* * *} p<0.05$.

\subsection{Temporal variability in the zooplankton excretory metabolism}

We chose a station located off the eastern coast of Gran Canaria to explore the temporal variability in the GDH/ $R_{\mathrm{NH}}^{+}$ ratios of zooplankton, as well as in other biochemical factors that could in some way be related to the excretory metabolism. While GDH activities increased slightly from $1.21 \mu \mathrm{mol} \mathrm{NH}_{4}^{+} \mathrm{mg}$ protein ${ }^{-1} \mathrm{~h}^{-1}$ during the mixing period $(\mathrm{CI}-\mathrm{LWB})$ to $1.58 \mu \mathrm{mol} \mathrm{NH}_{4}^{+} \mathrm{mg}_{\text {protein }}{ }^{-1} \mathrm{~h}^{-1}$ during the stratification (CI-ST), some other variables decreased sharply (Fig. 5). $R_{\mathrm{NH}_{4}^{+}}$declined by half from April to October, and the averaged intracellular glutamate was 4-times less concentrated in this latter period, resulting in a positive correlation between the $R_{\mathrm{NH}_{4}^{+}}$and the internal pool of glutamate (Fig. 6). During the whole study, the $R_{\mathrm{O}_{2}} / R_{\mathrm{NH}_{4}^{+}}$ratio remained relatively stable within the range of protein catabolism (below 13, see Fig. 5).

\section{Discussion}

\subsection{Zooplankton excretory metabolism between different marine regions}

Providing universal equations for ecological processes has long been a challenge in marine sciences (e.g., Arístegui and Montero, 1995; Ikeda et al., 2001), but there are so many factors involved in modulating the biological rates that rarely a single mathematical function can explain any given variable in all circumstances. Still, understanding the sources of variability in plankton metabolism will help to understand nutrient fluxes in the oceans. Since Bidigare and King (1981) introduced the GDH assay as an index of heterotrophic $\mathrm{NH}_{4}^{+}$release, it has been extensively used in oceanographic research to assess both nitrogen regeneration within aquatic ecosystems (Fernández-Urruzola et al., 2014; Hernández-León et al., 1999, among others) and vertical nitrogen fluxes. However, there is little knowledge 
Table 3: Regression analyses between $R_{\mathrm{NH}_{4}^{+}}$and GDH activities in different marine ecosystems. The relationship between the two variables is defined by the equation $G D H=a+b R_{\mathrm{NH}_{4}^{+}}$, where $a$ is the intercept and $b$, the slope. For comparison, all rates are expressed as $\mu \mathrm{mol} \mathrm{NH_{4 } ^ { + }} \mathrm{mg}$ protein $^{-1} \mathrm{~h}^{-1} . n$ stands for the number of data in each analysis, and SEE represents the standard error of estimates.

\begin{tabular}{|c|c|c|c|c|c|c|c|c|c|c|}
\hline Area & Group & Size $(\mu \mathrm{m})$ & $n$ & Slope & Intercept & $r^{2}$ & $F$ & $p$-value $(F$-test $)$ & $\operatorname{SEE}( \pm \%)$ & Reference \\
\hline \multirow[t]{4}{*}{ North Atlantic } & Mixed zooplankton & $100-500$ & 25 & $2.2^{* *}$ & 0.66 & 0.41 & 16.1 & 0.0005 & 18.9 & This study \\
\hline & & $500-1000$ & 25 & $1.6^{* * *}$ & 1.20 & 0.29 & 9.3 & 0.0056 & 21.4 & This study \\
\hline & & $>1000$ & 9 & $3.9^{\text {n.s. }}$ & 1.8 & 0.19 & 1.6 & 0.2422 & 21.8 & This study \\
\hline & & Total $(>100)$ & 59 & $1.7^{*}$ & 1.01 & 0.29 & 21.4 & $<0.0001$ & 15.0 & This study \\
\hline \multirow[t]{7}{*}{ Canary Islands - LWB } & Mysid (Leptomysis lingvura) & $>2 \times 10^{4}$ & 41 & $4.7^{*}$ & 0.58 & 0.81 & 124.1 & $<0.0001$ & 7.5 & Fernández-Urruzola et al. (2011) $)^{\dagger}$ \\
\hline & Mixed zooplankton & $100-1000$ & 59 & $3.8^{* *}$ & 1.09 & 0.20 & 14.3 & 0.0004 & 16.9 & Hernández-León and Torres (1997) \\
\hline & & $50-100$ & 11 & $4.4^{* * *}$ & -0.05 & 0.66 & 17.5 & 0.0023 & 17.9 & This study \\
\hline & & $100-200$ & 21 & $2.1^{*}$ & 0.29 & 0.56 & 24.3 & $<0.0001$ & 18.5 & This study \\
\hline & & $200-500$ & 29 & $2.3^{*}$ & 0.24 & 0.45 & 22.1 & $<0.0001$ & 27.0 & This study \\
\hline & & $500-1000$ & 15 & $3.0^{* * * *}$ & 0.45 & 0.34 & 6.7 & 0.0230 & 18.9 & This study \\
\hline & & Total $(50-1000)$ & 76 & $2.1^{*}$ & 0.38 & 0.44 & 58.4 & $<0.0001$ & 18.5 & This study \\
\hline \multirow[t]{5}{*}{ Canary Islands - ST } & Mixed zooplankton & $100-200$ & 14 & $13.3^{* *}$ & -0.48 & 0.61 & 18.5 & 0.0010 & 18.0 & This study \\
\hline & & $200-500$ & 18 & $13.9^{* * *}$ & 0.45 & 0.44 & 12.5 & 0.0028 & 23.4 & This study \\
\hline & & $500-1000$ & 15 & $18.4^{* *}$ & -0.32 & 0.59 & 18.8 & 0.0008 & 16.8 & This study \\
\hline & & $>1000$ & 8 & $11.3^{* * *}$ & -0.01 & 0.72 & 15.6 & 0.0076 & 16.1 & This study \\
\hline & & Total $(>100)$ & 55 & $13.3^{*}$ & -0.20 & 0.56 & 62.1 & $<0.0001$ & 14.1 & This study \\
\hline \multirow[t]{3}{*}{ Gulf of Maine } & Mysid (Praunus flexuosus) & $>4 \times 10^{4}$ & 8 & $43.8^{* *}$ & 0.96 & 0.92 & 64.2 & 0.0002 & 3.7 & Bidigare and King $(1981)^{\dagger}$ \\
\hline & Copepod (Calanus finmarchicus) & $>6000$ & 10 & 16.8 & - & - & - & - & 15.5 & Bidigare and King $(1981)^{*}$ \\
\hline & Mixed zooplankton & $>132$ & 8 & 23.4 & - & - & & & 17.1 & King et al. $(1987)^{*}$ \\
\hline Gulf of Mexico & Mixed zooplankton & $>333$ & 11 & 18.7 & - & - & & - & 23.0 & Bidigare et al. (1982)* \\
\hline Great South Bay & Mixed zooplankton & $>200$ & 10 & $24.3^{*}$ & -0.52 & 0.98 & 436.3 & $<0.0001$ & 4.1 & Park et al. $(1986)^{\dagger}$ \\
\hline Benguela upwelling system & Mixed zooplankton & $500-1000$ & 26 & $16.7^{*}$ & 0.40 & 0.49 & 23.4 & $<0.0001$ & 23.3 & This study \\
\hline \multirow[t]{4}{*}{ Indian Ocean } & Mixed zooplankton & $100-500$ & 8 & $2.9^{* * * *}$ & 0.33 & 0.59 & 8.5 & 0.0270 & 14.9 & This study \\
\hline & & $500-1000$ & 5 & $3.4^{* * *}$ & 0.48 & 0.88 & 24.2 & 0.0161 & 9.1 & This study \\
\hline & & $>1000$ & 6 & $2.2^{\text {n.s. }}$ & 0.49 & 0.31 & 1.8 & 0.2487 & 28.5 & This study \\
\hline & & Total $(>100)$ & 19 & $2.3^{* *}$ & 0.56 & 0.47 & 15.2 & 0.0010 & 17.1 & This study \\
\hline East Sea of Korea & Mixed zooplankton & $>350$ & 6 & $17.9^{* * * *}$ & 0.12 & 0.71 & 9.89 & 0.0347 & 13.8 & Park $(1986 b)^{\dagger}$ \\
\hline Strait of Georgia & Copepod (Neocalanus plumchrus) & $>4000$ & 4 & 15.3 & - & - & - & - & 28.1 & Campbell et al. (2004) \\
\hline
\end{tabular}

${ }^{*}$ Significant at a level $p<0.0001,{ }^{* *} p<0.001,{ }^{* * *} p<0.01$, and ${ }^{* * * *} p<0.05$. ${ }^{\text {n.s. }}$ stands for not significant slope $(p>0.05)$.

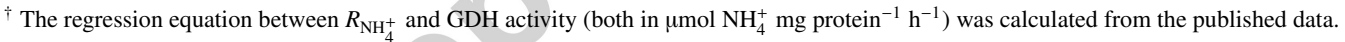

$\ddagger$ Only the averaged GDH $/ R_{\mathrm{NH}_{4}^{+}}$ratio and the correspondent coefficient of variation are provided in the original work.

of the variability in the GDH to $R_{\mathrm{NH}_{4}^{+}}$ratio that results from the large spatial and temporal heterogeneity in the marine environments. A proper calibration of this ratio throughout the world's oceans will lead to more meaningful estimations of $R_{\mathrm{NH}_{4}^{+}}$from GDH measurements.

Metabolic rates are known to vary as a function of body mass. In order to evaluate any potential effect of biomass in the relationship between the physiology $\left(R_{\mathrm{NH}_{4}^{+}}\right)$and the enzymology $(\mathrm{GDH})$, both rates were regressed against protein in Fig. 2. As Berges et al. (1993) pointed out, there would be no mass-specific influence in the GDH/ $R_{\mathrm{NH}_{4}^{+}}$ratio if both variables follow the same allometric principles, i.e., scale to the same exponent. Here, the slope for $R_{\mathrm{NH}_{4}^{+}}$was 0.87 , which means that smaller amounts of zooplankton excrete more $\mathrm{NH}_{4}^{+}$per unit protein than do larger amounts. This exponent falls in the range between 0.7 - 0.9 typical for marine planktonic metazoans (Ikeda et al., 2000). Nevertheless, 
densities of zooplankton were different in each sample, so bottle effects may also be a factor influencing our scalar component, with higher densities yielding lower $R_{\mathrm{NH}_{4}^{+}}$(Bidigare, 1983). Conversely, GDH activities showed the opposite trend, with a slope above $1.0(b=1.38)$. If larger sizes present more GDH but lower $R_{\mathrm{NH}_{4}^{+}}$per unit protein, then it should mean that the glutamate deamination becomes less efficient with biomass. This could be due not only to differences in the intracellular levels of glutamate (i.e., the enzyme become less saturated with increasing size), but also to differences in the kinetic constants of the GDH. In this context, Fernández-Urruzola et al. (2016) showed an increase in the half-saturation Michaelis constant $\left(\mathrm{K}_{\mathrm{m}}\right)$ with size, which means a lower affinity of the GDH for its substrates in the largest organisms. This dissimilarity in the scaling exponents would thus impact the relationship between GDH and $R_{\mathrm{NH}_{4}^{+}}$when analyzing samples with different biomass. Although organisms were fractionated in size categories, one should note that each mixed zooplankton sample was considered as a whole and therefore, the taxonomic composition and the size spectrum of organisms in the samples may introduce biases. Still, the scaling exponent for the GDH activities surpassed the correspondent value for the $R_{\mathrm{NH}_{4}^{+}}$by a similar magnitude in individual marine mysids with different protein content (Fernández-Urruzola et al., 2011). All this suggests that size fractionation of zooplankton samples is recommendable for reducing the mass effect when comparing metabolic measurements in populations with different size structures. Likewise, the use of particular GDH $/ R_{\mathrm{NH}_{4}^{+}}$ratios for each size fraction should improve the prediction of actual $R_{\mathrm{NH}_{4}^{+}}$. On the other hand, it is noteworthy that the dispersion in the $R_{\mathrm{NH}_{4}^{+}}$ was considerably higher compared to the one measured with the enzymatic rates. As has already been stated, bottle

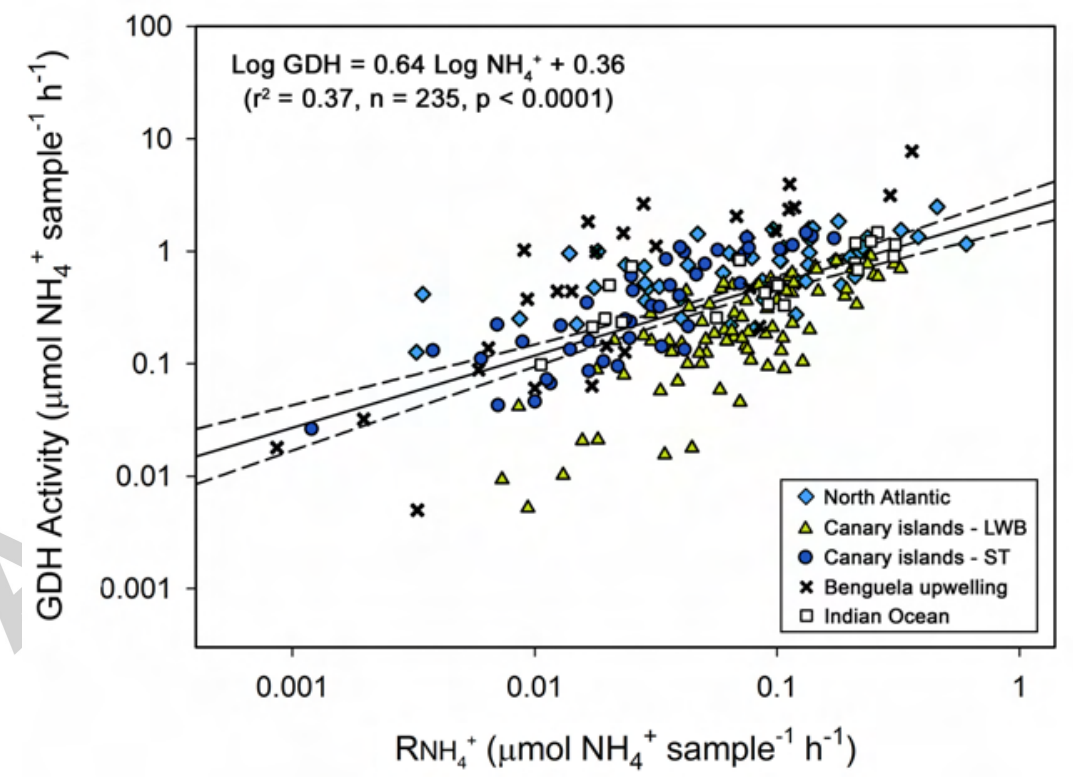

Figure 4: Log-transformed relationship between $R_{\mathrm{NH}_{4}^{+}}$and GDH activities. The regression includes all the experiments conducted during this research, where each dot represents a size fraction. Dashed lines stand for the $95 \% \mathrm{CIs}$. The standard error of estimate (SEE) amounts to $\pm 42.5 \%$. The correction factor ( $C F$, sensu Sprugel, 1983) to convert the equation into an arithmetic scale was 1.62. 
incubations are subject to many methodological constraints that may lead to differences in experimentally determined $R_{\mathrm{NH}_{4}^{+}}$values from in situ rates in a hardly predictable manner. Furthermore, differences in the trophic conditions between oceanic systems could also affect more the physiological than the enzymatically determined potential rates, as the latter are inherently less responsive to environmental changes (Bamstedt, 1980).

The size-fractionated comparison of the protein-specific excretory metabolism between regions yielded similar conclusions (Fig. 3). $R_{\mathrm{NH}_{4}^{+}}$per unit protein was generally higher in the smallest size fraction (100 - $\left.500 \mu \mathrm{m}\right)$, which concurs with the mass-specific $R_{\mathrm{NH}_{4}^{+}}$shown in Steinberg and Saba (2008) over a wide body mass range of marine zooplankton. However, as heralded by the scaling exponents, this pattern contrasted with the mass-specific GDH activities (Fig. $3 b$ ). Averaged specific $R_{\mathrm{NH}_{4}^{+}}$varied from a low of $0.09 \mu \mathrm{mol} \mathrm{N \textrm {NH } _ { 4 } ^ { + } \mathrm { mg } \text { protein }}{ }^{-1} \mathrm{~h}^{-1}$ in the BU region to a high of $0.38 \mu \mathrm{mol} \mathrm{NH}+4$ mg protein ${ }^{-1} \mathrm{~h}^{-1}$ in the CI-LWB. These values fitted reasonably well with the specific $R_{\mathrm{NH}_{4}^{+}}$ range $\left(0.13-0.27 \mu \mathrm{mol} \mathrm{NH} \mathrm{NH}_{4}^{+} \mathrm{mg}_{\text {protein }}{ }^{-1} \mathrm{~h}^{-1}\right)$ predicted by the equations of Ikeda (1985). They were also close to the lower limit of the range provided in Hernández-León et al. (2008) for subtropical and temperate waters, which varied between $0.43-0.67 \mu \mathrm{mol} \mathrm{NH}+\mathrm{mg}_{4}$ protein ${ }^{-1} \mathrm{~h}^{-1}$, after a nitrogen to protein conversion factor of 0.52 given by Postel et al. (2000) for mixed zooplankton communities. Nevertheless, these rates are not static, but fluctuate seasonally according to the different feeding and temperature scenarios. In fact, the metabolic rates are highly dependent on the environmental temperature and as such, $R_{\mathrm{NH}_{4}^{+}}$reached its minimum in the coldest waters of the BU despite being the most productive system in this study (see Table 1). Applying a $\mathrm{Q}_{10}$ of 3.60 (Hernández-León et al., 2008) and

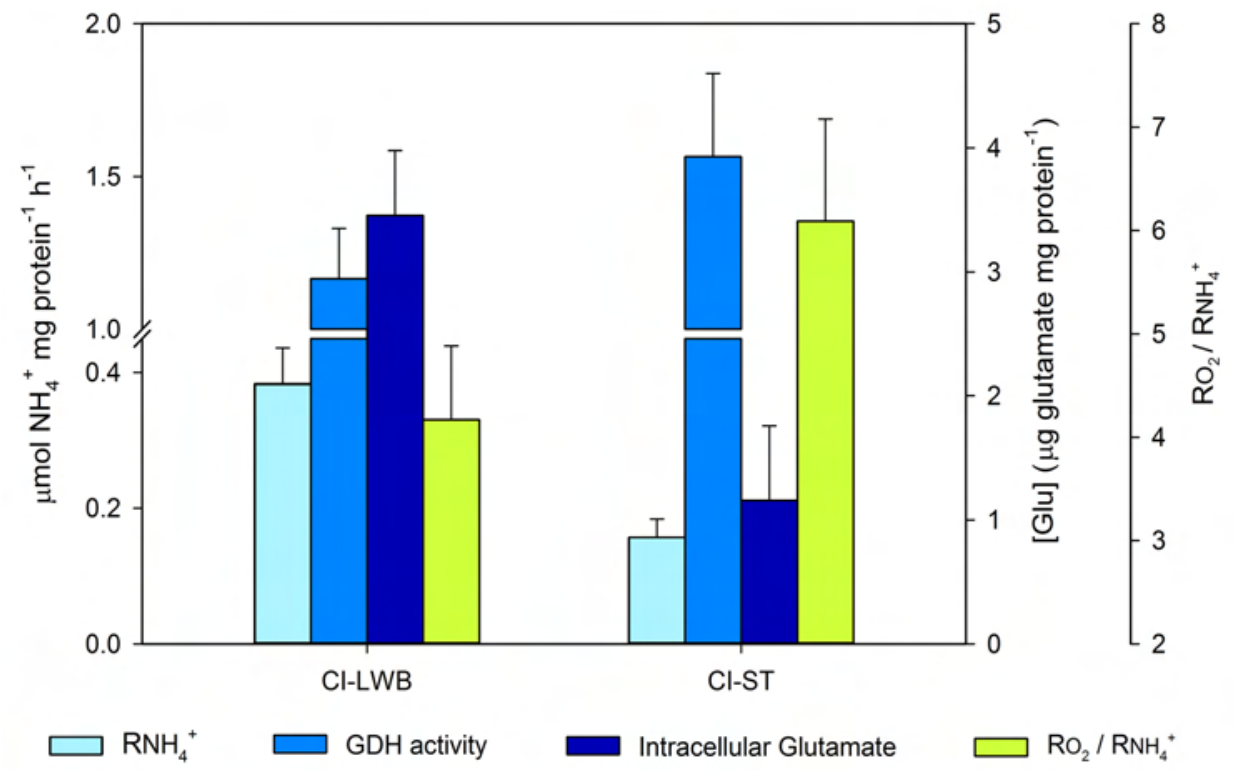

Figure 5: $R_{\mathrm{NH}_{4}^{+}}\left(\mu \mathrm{mol} \mathrm{NH} \mathrm{NH}_{4}^{+} \mathrm{mg}\right.$ protein $\left.{ }^{-1} \mathrm{~h}^{-1}\right)$, GDH activities $\left(\mu \mathrm{mol} \mathrm{NH} \mathrm{NH}_{4}^{+} \mathrm{mg}_{\text {protein }}{ }^{-1} \mathrm{~h}^{-1}\right)$, intracellular glutamate concentration $(\mu \mathrm{g}$ glutamate mg protein ${ }^{-1}$ ) and $R_{\mathrm{O}_{2}} / R_{\mathrm{NH}_{4}^{+}}$ratios measured in the zooplankton from the Canary islands during the "late winter bloom" (CI-LWB), and during the stratification period (CI-ST). Error bars indicate the $95 \%$ CIs. 
standardizing by the highest temperature $\left(25.1^{\circ} \mathrm{C}\right)$, the specific rates in the BU would reach values as high as those found in the NA $\left(0.35 \mu \mathrm{mol} \mathrm{NH} \mathrm{NH}_{4}^{+} \mathrm{mg}\right.$ protein $\left.{ }^{-1} \mathrm{~h}^{-1}\right)$. A similar temperature dependency should be considered for the catalytic activity of enzymes (Packard et al., 1975; Park et al., 1986). Particularly interesting was the wide range of protein-specific GDH activities found in the BU (Fig. 3b). Upwelling systems are complex ecosystems that give rise to a variety of metabolic states in heterogenous plankton communities that result from the interplay of water masses with different age and production histories (Fernández-Urruzola et al., 2014). These waters hold exponentially growing populations with net anabolic processes, as well as non-growing mature populations characterized largely by catabolism. All this may lead to different levels of intracellular GTP across assemblages that would produce an uneven inhibition in the GDH activities. Furthermore, studies have shown great variability in the mass-specific metabolism when comparing multiple taxa (Steinberg and Saba, 2008). The relative contribution of gelatinous and crustacean zooplankton in the samples could thus explain some differences in the metabolic rates between oceanic systems. On a dry mass basis, $R_{\mathrm{NH}_{4}^{+}}$has been found to be an order of magnitude lower in gelatinous zooplankton, even though such a difference becomes smaller when using carbon as a reference (Schneider, 1990). This means that the mass unit used for standardization largely determines both the specific $R_{\mathrm{NH}_{4}^{+}}$and GDH activities. Accordingly, any metabolic rate should be compared on the same mass basis, which also should be applied to comparisons between dimensionless variables such as the aforementioned scaling exponents and the $\mathrm{GDH} / \mathrm{R}_{\mathrm{NH}_{4}^{+}}$ratios. Enzymatic rates are usually scaled to protein because it is a relatively straightforward parameter to measure in the same homogenate and therefore, our size fractionated GDH to $R_{\mathrm{NH}_{4}^{+}}$ratios were compared with those from literature in terms of protein (Table 3). Nevertheless, mass standardization assumes that body size is not a factor (Berges et al., 1993), so we pooled all our rates without standardization in Fig. 4.

Previous studies on the respiratory metabolism suggested that the regression models between enzymatic and physiological rates would produce lower errors than averaging individual ratios (Arístegui and Montero, 1995; Packard and Williams, 1981). In our study, the mean standard error of the regression analyses that were applied to each data set amounted to $\pm 17.6 \%$ (Table 3$)$, while the mean coefficient of variation $(C V=100 \times S D \div \bar{x})$ of the averaged ratios rose to $\pm 60.4 \%$. This evidences the superiority of the former approach. Its error, however, increased up to $\pm 42.6 \%$ when regressing all data together (Eq. 3). Still, these uncertainties associated with the GDH/ $R_{\mathrm{NH}}^{+}$ratios were on the same order than those produced by other standard techniques used in ecological procedures for plankton metabolism (King and Packard, 1975; Richardson, 1991). In general, GDH activities correlated well with $R_{\mathrm{NH}_{4}^{+}}$in all the marine ecosystems, with the analyses being significant mostly at a level of $p<0.01$. The highest coefficient of determination $\left(r^{2}\right)$ was obtained in those monospecific cultures of mysids that were maintained under laboratory controlled conditions (Bidigare and King, 1981; Fernández-Urruzola et al., 2011). Working with natural mixed zooplankton assemblages, only Park et al. (1986) achieved a better correlation between GDH activities and $R_{\mathrm{NH}_{4}^{+}}$. The relationship between the two rates was highly variable across marine ecosystems, and ranged from 1.7 for the whole community from the NA to 43.8 in the mysid Praunus flexuosus (Bidigare and King, 1981) from the Gulf of Maine. As discussed above, multiple factors that are inherent in the zooplankton communities such as biomass, growth, feed- 
ing and taxonomy, determine the relationship between biochemistry and physiology. Physiological rates have been found to be closer to their potential rates in non-gelatinous zooplankton than in gelatinous zooplankters (King and Packard, 1975); the same is expected for small, growing and well-fed zooplankton (Fernández-Urruzola et al., 2011). It should be further considered that some transaminases may synthesize $\mathrm{NH}_{4}^{+}$and therefore, they could contribute to the mismatch between the $R_{\mathrm{NH}_{4}^{+}}$and the GDH activities. Still, the role of enzymes such as glutaminase and AMPdeaminase in producing $\mathrm{NH}_{4}^{+}$would be minor as compared to the GDH (Regnault, 1987). Aside from these biological constraints, one could assume that other methodological artifacts derived from manipulation (e.g., stress, injury or crowding) and analytical procedures influence the measurement equally, but this is probably not the case. Therefore, a single function can hardly consider all these sources of variability, so its ability to predict $R_{\mathrm{NH}_{4}^{+}}$in various ecosystems and zooplankton communities would be limited (Eq. 3). Nevertheless, its accuracy seems to be improved to some extent if environmental parameters such as temperature and chlorophyll-a are considered in the function (Eq. 4). In the less complex case of prokaryotes and nanozooplankton, a general equation may yield more accurate predictions of $R_{\mathrm{NH}_{4}^{+}}$from GDH measurements, as demonstrated by Arístegui and Montero (1995) in a respiratory metabolism case study.

\subsection{Temporal variability in the zooplankton excretory metabolism}

Table 3 shows that seasonal changes in the GDH/ $R_{\mathrm{NH}_{4}^{+}}$ratios in the same location can be higher than the variation measured between regions. During the late winter bloom (CI-LWB), which usually occurs from January to April in

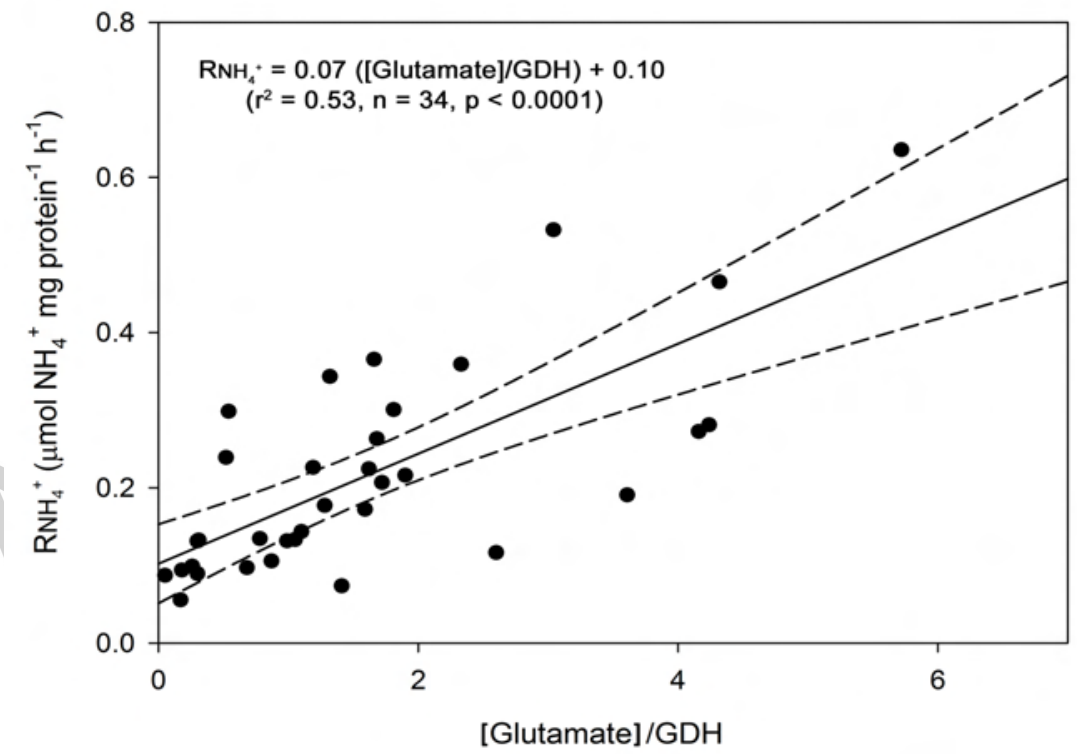

Figure 6: Relationship between $R_{\mathrm{NH}_{4}^{+}}$and the glutamate concentration ( $\mu$ g glutamate mg protein ${ }^{-1}$ ) standardized by the GDH activities ( $\mu$ mol $\mathrm{NH}_{4}^{+}$ mg protein ${ }^{-1} \mathrm{~h}^{-1}$ ) in waters off Gran Canaria. Dashed lines stand for the $95 \%$ CIs. 
the Canary Island region, the erosion of the thermocline allows the entrainment of nutrients into the euphotic zone, leading to increased primary productivity (De León and Braun, 1973). This was reflected in the higher chlorophyll-a concentration during CI-LWB as compared to the stratification period, CI-ST (Table 1). At that time, zooplankton released an average of $0.39 \mu \mathrm{mol} \mathrm{NH} \mathrm{mg}_{4}^{+} \mathrm{mrotein}^{-1} \mathrm{~h}^{-1}$, twice the protein-specific $R_{\mathrm{NH}_{4}^{+}}$found during CI-ST (Fig. 5). Hernández-León and Torres (1997) monitored the mesozooplankton $R_{\mathrm{NH}_{4}^{+}}$from November to May off Gran Canaria island, and also found great variability in the rates according to the trophic fluctuations (ranging between 0.02 - 0.71 $\mu \mathrm{mol} \mathrm{NH}_{4}^{+} \mathrm{mg}$ protein ${ }^{-1} \mathrm{~h}^{-1}$ ). Similar to our findings, their GDH activities did not follow the $R_{\mathrm{NH}_{4}^{+}}$pattern, which led to different GDH/ $R_{\mathrm{NH}_{4}^{+}}$ratios during their study period. In fact, several studies have found that the specific GDH activities did not peak in the chlorophyll-a maximum, but rather it was attenuated (Fernández-Urruzola et al., 2014; Hernández-León et al., 2001; Park et al., 1986). On the one hand, it seems reasonable to presume that the plankton community was growing during the CI-LWB and therefore, it was in an earlier developmental stage (sensu Vinogradov and Shushkina, 1978) as compared to the community from the CI-ST. Nitrogen may thus limit biosynthesis, so it would not be energetically efficient to produce an excess of enzyme. Another plausible biochemical explanation was given by Park et al. (1986), who suggested a strong inhibition by the high GTP concentration generated via the tricarboxilic acid cycle in those organisms that were actively growing under favourable trophic conditions. In such a situation, GDH activities may be underestimated by the standard assay, since it would require higher levels of ADP to counteract the GTP effect. This could explain the lower $\mathrm{GDH} / R_{\mathrm{NH}_{4}^{+}}$ratios during conditions of high prey abundance, as well as differences in the values of the $y$-intercepts observed in Table 3. Similar behavior in the ratio was observed when zooplankters were exposed to starvation in laboratory experiments (Fernández-Urruzola et al., 2011; Park, 1986a). In addition to the allosterism associated with GTP, GDH is known to be controlled by the internal pool of glutamate. As in all enzymes, the substrate concentrations determine the actual rate at which the reaction can operate (Bisswanger, 2008); however, few attempts have been made to measure them directly. Park et al. (1986) calculated the effective glutamate concentration from kinetic parameters in macrozooplankton, and showed an increase of the glutamate pool linked with those periods of food availability. Similar findings have been made regarding the respiratory metabolism, for exampe Osma et al. (2016) measured a decrease in the levels of pyridine nucleotides in the marine dinoflagellate Oxyrrhis marina as organisms starved. In our study, internal glutamate decreased dramatically from April to October, which supports the hypothesis of substrate levels as a key mechanism in the regulation of $R_{\mathrm{NH}_{4}^{+}}$ (Hernández-León and Torres, 1997). Accordingly, the higher glutamate availability may lead the organisms to excrete more $\mathrm{NH}_{4}^{+}$per unit protein during the late winter bloom. The significant correlation between these two variables (Fig. 6) reinforces the utility of kinetic-based models in the study of zooplankton metabolism (Packard and Gómez, 2008). The measurement of biochemical parameters such as the Michaelis constant $\left(K_{\mathrm{m}}\right)$, jointly with the intracellular levels of both the substrates and allosteric regulators, would therefore open new avenues in the approximation of the in vivo $R_{\mathrm{NH}_{4}^{+}}$from GDH activities. Furthermore, we studied the relationship between the respiration rates $\left(R_{\mathrm{O}_{2}}\right)$ and the $R_{\mathrm{NH}_{4}^{+}}$ because it serves as an index of catabolism (Mayzaud and Conover, 1988). Although it was slightly higher during CI-ST, the low values reflected a protein-based catabolism during the two sampling periods. This is not surprising 
since the small microheterotrophs, poor in fatty acids, constitute $35-80 \%$ of the diet of mesozooplankton in these waters (Hernández-León et al., 2004). So rather than a shift in the diet, changes in the availability of prey seem to be responsible for the variability measured in the zooplankton excretory metabolism.

\section{Conclusions}

GDH is an essential tool for mapping zooplankton $R_{\mathrm{NH}_{4}^{+}}$throughout the oceans. Unfortunately, the statistical relationship as measured by $\mathrm{GDH} / R_{\mathrm{NH}_{4}^{+}}$, the ratio between enzymatic and physiological rates, is not universal. In this research we found that temporal variability in the $\mathrm{GDH} / R_{\mathrm{NH}_{4}^{+}}$ratios from the same ecosystem could be higher than those between regions. Both GDH activities and $R_{\mathrm{NH}_{4}^{+}}$maintained differently allometric relationships with biomass, which has to be considered when comparing communities with different sized animals. Still, this effect should be studied on specific taxa and controlled culture conditions in order to avoid any interference from other sources of variability. On the other hand, abundance of prey is known to be a key factor in modulating the metabolic rates of zooplankton. Here we observed fluctuations in the internal glutamate pool according to the productivity regime, in parallel to the $R_{\mathrm{NH}_{4}^{+}}$trends. How this variation affects the actual enzymatic rates needs to be further investigated. Given the variability in the GDH activity to $R_{\mathrm{NH}_{4}^{+}}$relationship, we encourage a field calibration of this ratio for each specific community being studied.

Acknowledgements. We wish to thank the crews of the BIO Hespérides, BIO Atlantic Explorer, and RV Maria S. Merian for their expertise and enthusiastic support. We thank L. Postel and C. M. Duarte for their invitation to participate in the "SUCCESSION" (I. F.-U.) and "MALASPINA 2010" (F. M., N. O., I. F.-U.) cruises. We are also grateful to M. Estrada and P. Mozetic for providing the chlorophyll data from the MALASPINA 2010 cruise. Two anonymous reviewers notably improved the manuscript with their valuables suggestions. Funding was provided, in part, by the German Research Foundation (DFG), and by the MALASPINA 2010 (CSD2008-00077) and the BIOMBA (CTM2012-32729/MAR) projects granted to C. M. Duarte and M. G., respectively. I.F.-U. and N.O. were supported by postgraduate grants from the Formation and Perfection of the Researcher Personel Program from the Basque Government. T.T. P. was largely supported by TIAA-CREF and Social Security (USA).

\section{References}

Arístegui, J., Montero, M.F., 1995. The relationship between community respiration and ETS activity in the ocean. J. Plankton Res. 17 (7), $1563-1571$

Bamstedt, U., 1980. ETS activity as an estimator of respiratory rate of zooplankton populations. The significance of variations in environmental factors. J. Exp. Mar. Biol. Ecol. 42 (3), 267-283.

Berges, J.A., Roff, J.C., Ballantyne, J.S., 1993. Enzymatic indices of respiration and ammonia excretion: relationships to body size and food levels. J. Plankton Res. 15 (2), 239-254.

Bidigare, R.R., 1983. Nitrogen excretion by marine zooplankton. In: E.J. Carpenter, D.G. Capone (Eds.), Nitrogen in the marine environment. Academic Press, Inc., New York, pp. 385-409.

Bidigare, R.R., King, F.D., 1981. The measurement of glutamate dehydrogenase activity in Praunus flexuosus and its role in the regulation of ammonium excretion. Comp. Biochem. Physiol. 70 (B), 409-413. 
Bidigare, R.R., King, F.D., Biggs, D.C., 1982. Glutamate dehydrogenase (GDH) and respiratory electron-transport-system (ETS) activities in Gulf of México zooplankton. J. Plankton Res. 4 (4), 895-911.

Bisswanger, H., 2008. Enzyme kinetics: Principles and methods. 2nd ed. Wiley-VCH Verlag GmbH \& Co., Weinheim, 301 pp.

Bode, A., Barquero, S., González, N., Álvarez-Ossorio, M.T., Varela, M., 2004. Contribution of heterotrophic plankton to nitrogen regeneration in the upwelling ecosystem of A Coruña (NW Spain). J. Plankton Res. 26 (1), 11-28.

Bronk, D.A., Steinberg, D.K., 2008. Nitrogen regeneration. In: E.J. Carpenter, D.G. Capone (Eds.), Nitrogen in the marine environment. Academic Press, London, pp. 385-467.

Campbell, R.W., Boutillier, P., Dower, J.F., 2004. Ecophysiology of overwintering in the copepod Neocalanus plumchrus: changes in lipid and protein contents over a seasonal cycle. Mar. Ecol. Prog. Ser. 280, 211-226.

De León, A.R., Braun, J.G., 1973. Annual cycle of primary production and its relation to nutrients in the Canary Islands waters. Bol. Inst. Esp. Oceanogr. 167, 1-24.

Eppley, R.W., 1978. Nitrate reductase in marine phytoplankton. In: J.A. Hellebust, J.S. Craige (Eds.), Handbook of phycological methods. Physiological and biochemical methods. Cambridge University Press, Cambridge, pp. 217-223.

Fernández-Urruzola, I., Osma, N., Gómez, M., Montesdeoca-Esponda, S., Packard, T.T., 2016. Building a model of ammonium excretion in two species of marine zooplankton based on glutamate dehydrogenase kinetics. Mar. Ecol. Prog. Ser. 550, 83-99.

Fernández-Urruzola, I., Osma, N., Packard, T.T., Gómez, M., Postel, L., 2014. Distribution of zooplankton biomass and potential metabolic activities across the northern Benguela upwelling system. J. Mar. Syst. 140 (B), 138-149.

Fernández-Urruzola, I., Packard, T.T., Gómez, M., 2011. GDH activity and ammonium excretion in the marine mysid, Leptomysis lingvura: Effects of age and starvation. J. Exp. Mar. Biol. Ecol. 409 (1-2), 21-29.

Hans-Otto, B., Michal, G., 1974. L-glutamate: Determination with glutamate dehydrogenase, diaphorase, and Tetrazolium salts. In: H.U. Bergmeyer (Ed.), Methods of enzymatic analysis. Verlag Chemie GmbH, pp. 1708-1713.

Harrison, W.G., 1992. Regeneration of nutrients. In: P.G. Falkowski, A.D. Woodhead (Eds.), Primary productivity and biogeochemical cycles in the sea. Plenum Press, New York, pp. 385-409.

Hernández-León, S., Almeida, C., Bécognée, P., Yebra, L., Arístegui, J., 2004. Zooplankton biomass and indices of grazing and metabolism during a late winter bloom in subtropical waters. Mar. Biol. 145 (6), 1191-1200.

Hernández-León, S., Almeida, C., Gómez, M., Torres, S., Montero, I., Portillo-Hahnefeld, A., 2001. Zooplankton biomass and indices of feeding and metabolism in island-generated eddies around Gran Canaria. J. Mar. Syst. 30 (1-2), 51-66.

Hernández-León, S., Fraga, C., Ikeda, T., 2008. A global estimation of mesozooplankton ammonium excretion in the open ocean. J. Plankton Res. $30(5), 577-585$

Hernández-León, S., Postel, L., Arístegui, J., Gómez, M., Montero, M.F., Torres, S., Almeida, C., Kühner, E., Brenning, U., Hagen, E., 1999. Large-scale and mesoscale distribution of plankton biomass and metabolic activity in the Northeastern Central Atlantic. J. Oceanogr. 55, $471-482$.

Hernández-León, S., Torres, S., 1997. The relationship between ammonia excretion and GDH activity in marine zooplankton. J. Plankton Res. $19(5), 587-601$.

Herrera, A., Packard, T., Santana, A., Gómez, M., 2011. Effect of starvation and feeding on respiratory metabolism in Leptomysis lingvura (G.O. Sars, 1866). J. Exp. Mar. Biol. Ecol. 409, 154-159.

Holmes, R.M., Aminot, A., Kérouel, R., Hooker, B.A., Peterson, B.J., 1999. A simple and precise method for measuring ammonium in marine and freshwater ecosystems. Can. J. Fish. Aquat. Sci. 56, 1801-1808.

Ikeda, T., 1985. Metabolic rates of epipelagic marine zooplankton as a function of body mass and temperature. Mar. Biol. 85, 1-11.

Ikeda, T., Fay, E.H., Hutchinson, S.A., Boto, G.M., 1982. Ammonia and inorganic phosphate excretion by zooplankton from inshore waters of the Great Barrier Reef, Queensland. I. Relationship between excretion rates and body size. Mar. Freshwater Res. 33 (1), 55-70.

Ikeda, T., Kanno, Y., Ozaki, K., Shinada, A., 2001. Metabolic rates of epipelagic marine copepods as a function of body mass and temperature. Mar. Biol. 139, 587-596. 
Ikeda, T., Torres, J.J., Hernández-León, S., Geiger, S.P., 2000. Metabolism. In: R.P. Harris, P.H. Wiebe, J. Lenz, H.R. Skjoldal, M. Huntley (Eds.), ICES Zooplankton methodology manual. Academic Press, San Diego, pp. 455-532.

Isla, J.A., Llope, M., Anadón, R., 2004. Size-fractionated mesozooplankton biomass, metabolism and grazing along a $50^{\circ} \mathrm{N}-30^{\circ} \mathrm{S}$ transect of the Atlantic Ocean. J. Plankton Res. 26 (11), 1301-1313.

King, F.D., Cucci, T.L., Townsend, D.W., 1987. Microzooplankton and macrozooplancton glutamate dehydrogenase as indices of the relative contribution of these fractions to ammonium regeneration in the Gulf of Maine. J. Plankton Res. 9 (2), $277-289$.

King, F.D., Packard, T.T., 1975. Respiration and the activity of the respiratory electron transport system in marine zooplankton. Limnol. Oceanogr. $20(5), 849-854$.

Lowry, O.H., Rosebrough, N.J., Farr, A.L., Randall, R.J., 1951. Protein measurement with the Folin phenol reagent. J. Biol. Chem. 193, 265-275.

Mayzaud, P., Conover, R.J., 1988. 0:N atomic ratio as a tool to describe zooplankton metabolism. Mar. Ecol. Prog. Ser. 45, 289-302.

Osma, N., Aristizabal, M., Fernández-Urruzola, I., Packard, T.T., Gómez, M., 2016. Influence of starvation on respiratory metabolism and pyridine nucleotide levels in the marine dinoflagellate Oxyrrhis marina. Protist 167 (2), 136-147.

Owens, T., King, F.D., 1975. The measurement of respiratory electron transport system activity in marine zooplankton. Mar. Biol. 30 (1), 27-36.

Packard, T.T., Devol, A., King, F.D., 1975. The effect of temperature on the respiratory electron transport system in marine plankton. Deep-Sea Res 22 (4), 237-249.

Packard, T.T., Gómez, M., 2008. Exploring a first-principles-based model for zooplankton respiration. ICES J. Mar. Sci. 65 (3), $371-378$.

Packard, T.T., Healy, M.L., Richards, F.A., 1971. Vertical distribution of the activity of the respiratory electron transport system in marine plankton. Limnol. Oceanogr. 16 (1), 60-70.

Packard, T.T., Williams, P.J.L., 1981. Rates of respiratory oxygen consumption and electron transport in surface seawater from the northwest Atlantic. Oceanol. Acta 4 (3), 351-358.

Park, Y.C., 1986a. Impact of starvation and feeding experiments on ammonium excretion and glutamate dehydrogenase activity of zooplankton. Kor. Biochem. J. 19 (1), 251-256.

Park, Y.C., 1986b. Nitrogen regeneration and glutamate dehydrogenase activity of macrozooplankton in the Southeastern Sea of Korea. J. Oceanol. Soc. Korea 21 (2), 110-117.

Park, Y.C., Carpenter, E.J., Falkowski, P.G., 1986. Ammonium excretion and glutamate dehydrogenase activity of zooplankton in Great South Bay, New York. J. Plankton Res. 8 (3), 489-503.

Parsons, T.R., Maita, Y., Lalli, C.M., 1984. Manual of chemical and biological methods for seawater analysis. Pergamon Press, New York, 173 pp. Postel, L., Fock, H., Hagen, W., 2000. Biomass and abundance. In: R.P. Harris, P.H. Wiebe, J. Lenz, H.R. Skjoldal, M. Huntley (Eds.), ICES Zooplankton methodology manual. Academic Press, San Diego, pp. 83-192.

Regnault, M., 1987. Nitrogen excretion in marine and fresh-water crustacea. Biol. Rev. 62, 1-24.

Richardson, K., 1991. Comparison of ${ }^{14}$ C primary production determinations made by different laboratories. Mar. Ecol. Prog. Ser. 72, $189-201$.

Rutter, W.J., 1967. Protein determination in embryos. In: F.H. Wilt, N.V. Wessels (Eds.), Methods in Developmental Biology. Academic Press, London, pp. 671-684.

Sameoto, D., Wiebe, P., Runge, J., Postel, L., Dunn, J., Miller, C., Coombs, S., 2000. Collecting zooplankton. In: ICES Zooplankton methodology manual. Academic Press, San Diego, pp. 55-81.

Schneider, G., 1990. A comparison of carbon based ammonia excretion rates between gelatinous and non-gelatinous zooplankton: Implications and consequences. Mar. Biol. 106 (2), 219-225.

Solorzano, L., 1969. Determination of ammonia in natural waters by the phenolhypochlorite method. Limnol. Oceanogr. 14 (5), $799-801$.

Sprugel, D.G., 1983. Correcting for bias in log-transformed allometic equations. Ecology 64 (1), 209-210.

Steinberg, D.K., Saba, G.K., 2008. Nitrogen consumption and metabolism in marine zooplankton . In: E.J. Carpenter, D.G. Capone (Eds.), Nitrogen in the marine environment. Academic Press, London, pp. 1135-1196.

Yentsch, C.S., Menzel, D.W., 1963. A method for the determination of phytoplankton chlorophyll and phaeophytin by fluorescence. In: Deep Sea Research and Oceanographic Abstracts. Elsevier, pp. 221-231. 